\title{
Awareness and Attitudes towards Cervical Cancer Screening with Paps Smear and Its Utilization among Female Undergraduates in Makurdi, North Central Nigeria
}

\author{
Michael Tyodoo Maanongun*, Andrea Avershima Ornguze, Peter Onche Eka, \\ Austin Ochigbo Ojabo, Terrumun Zaiyol Swende, Samuel Kuma Hemba-Hilekaan \\ Department of Obstetrics and Gynaecology, College of Health Sciences, Benue State University, Makurdi, Nigeria \\ Email: *maanongun@yahoo.com
}

How to cite this paper: Maanongun, M.T., Ornguze, A.A., Eka, P.O., Ojabo, A.O., Swende, T.Z. and Hemba-Hilekaan, S.K. (2017) Awareness and Attitudes towards Cervical Cancer Screening with Paps Smear and Its Utilization among Female Undergraduates in Makurdi, North Central Nigeria. Open Access Library Journal, 4: e3966.

https://doi.org/10.4236/oalib.1103966

Received: September 23, 2017

Accepted: November 20, 2017

Published: November 23, 2017

Copyright $\odot 2017$ by authors and Open Access Library Inc.

This work is licensed under the Creative Commons Attribution International License (CC BY 4.0).

http://creativecommons.org/licenses/by/4.0/

\begin{abstract}
Background: The awareness of cervical cancer, Papanicolaou's smear and its utilization is of great importance especially in our environment where cervical cancer is the number one cancer affecting women. This study was aimed at investigating the risk factors and awareness of cervical cancer screening with Papanicolaou's (Pap) smear and its utilization among female undergraduates. Materials and Method: This is a descriptive cross-sectional study that was conducted among 397 female undergraduates of the Benue State University, Makurdi between May and June 2016. Results: One hundred and eighty-six (49.6\%) of the respondents were sexually active and ninety-six (51.6\%) of the sexually active respondents had been exposed before the age of 20 years. Their ages for sexual debut ranged from 13 to 25 years. Their mean age at sexual debut was $18.3( \pm 2.3)$ while the modal age was 19 years. Fifty-one $(27.4 \%)$ of the sexually active students had multiple sexual partners, sixty-three (33.9\%) had been pregnant at one time or the other, and only 32 (17.2\%) of these sexually active students were using condom during intercourse. Two hundred and eighty-six $(72.0 \%)$ were aware of cervical cancer. There was a fair level (55.7\%) of awareness of cervical cancer as a preventable cancer but there was poor knowledge of individual preventive methods. Only 26.2\% were aware of Pap smear and worse still, only $3.3 \%$ of them had ever done the test. The main source of awareness was through the mass media. Conclusion: This study showed that there was good knowledge of cervical cancer among respondent but there was poor knowledge of Pap smear and its utilization. It is therefore important that concerted efforts be made to educate students at the university about cervical cancer and its prevention methods.
\end{abstract}




\section{Subject Areas}

Gynecology \& Obstetrics

\section{Keywords}

Awareness, Utilization, Pap Smear, Cervical Cancer, Screening

\section{Introduction}

Cervical cancer poses a major public health threat to women in many low and medium resourced countries in sub-Saharan Africa, Central America, South and South East Asia where it is still the leading type of cancer among women [1] [2]. With about 500,000 new cases and 250,000 deaths each year, cervical cancer is the second most common cancer in women (second only to breast cancer) [3] and the most common gynaecological cancer worldwide [4] [5]

The Human Papilloma Virus (HPV) is the leading cause of cervical cancer and is also the commonest cause of viral sexually transmitted infection in the world [6]. The virus exerts greater effects during period of metaplasia in the cervical epithelium mostly in the period of adolescence [7]. Also certain sexual behaviours are known to predispose one to cancer of the cervix. These include early sexual debut (earlier than the age of 20 years) and sexual promiscuity, either in the patient or her partner. The number of sexual partners is the major independent risk factor where as age at first sexual intercourse is a confounder [7] [8]. Other risk factors include high parity and low socioeconomic status. These factors are prevalent in Nigeria and other developing countries [8]

Cervical cancer is one of the most preventable human cancers because of its slow progression, cytological identifiable precursors and effective treatment if detected early. Papaniculaou (pap) test also known as cervical cytology screening has helped to reduce cervical cancer rate dramatically through the detection of premalignant lesions [9] [10]. Alternative screening approaches such as Visual Inspection with Acetic acid (VIA), Visual Inspection using Lugols iodine (VILI), Cervicography and Speculoscopy have also been explored in the prevention of cervical cancer in resource-poor settings [9] [11]. It has however been noted that most screening activities in developing countries do not reach the vulnerable women and consequently, a high proportion of cervical cancer cases are diagnosed at the advanced stages of the disease [9].

The availability of simple screening test for detection of treatable pre-invasive and early invasive cervical cancer, particularly periodic Pap's smear, makes the disease amenable to prevention and cure at the early stage of its evolution [7]. This screening modality has been shown to have significantly reduced the mortality associated with cervical cancer and is therefore recommended for all sexually active women [7] [12]. Papanicolaou and Traut in 1941 described the Pap smear test for cervical screening, which is said to have the potential to reduce the 
incidence of cervical cancer by $75 \%$ - 90\% [13]

In Nigeria, the lower age limit for admission into most tertiary institution is 16 years [7]. Therefore many undergraduates will be in their late teens and early twenties [7] [14]. As a result of the risk-taking behaviour in this age group, they are thought to be at increased risk of sexually transmitted diseases and possibly cervical cancer later in life [14] [15]. Some reasons that have been adduced for this risk taking behavior include the fact that most of the undergraduates live away from home in school hostels or rented houses, thereby weakening parental control or supervision. They become exposed to influences that encourage casual sexual relationship and have to take important decisions about their social and reproductive lives [7] [15]. Many of these undergraduates experiment with unprotected sex and multiple sexual partners as a result of intense peer influence [15].

In general, awareness about cervical cancer, availability of effective screening programs, and improvement of existing health services could reduce its burden among women. One of the reasons for its high incidence and mortality between developed and developing countries is the lack of awareness among the population, health care providers and policy makers [16] [17]. Thus the provision of information and acquisition of knowledge on the etiology of the disease and how it can be prevented could reduce exposure to known risk factors [16]. The more knowledgeable women are about Pap testing, the more likely they are to make a screening visit and to adhere to recommended follow-up for an abnormal result [18]. It has also been reported that $50 \%$ - $90 \%$ of women who develop or die from cervical cancer have never been screened [19].

The major sources of information about various reproductive health matters and programs amongst young people include relations and friends, schools, health facilities, mass media and public lectures among others. In recent times however, the use of the internet is becoming increasingly popular among Nigerian undergraduates and young people in general. It is observed that the internet can be a practical accessible way of delivering sexual health education to the young people, particularly if it is incorporated into websites they enjoy [7]. The utilization of cervical screening services has been low due to absence of knowledge about the disease, lack of familiarity with the concept of preventive health care, poor quality of health services, limited human resources, and geographic and economic inaccessibility of services [9] [20].

The majority of cancer cases seen in Nigeria occur between 35 and 65 years of age and it takes about 10 to 15 years of progression to invasive disease to occur [7]. Therefore many of the patients that develop cancer of the cervix would have had pre-invasive lesions as early as the age of 20 to 25 years [7] [21]. Elsewhere, studies to determine the knowledge and the utilization of Pap's Smear screening for prevention of cervical cancer have been done on groups of women including undergraduates [4] [7] [9] [16]. But is not so in our environment. The study seeks to provide base line knowledge of and attitude to cervical cancer, Papanicolaou cervical screening method and the high risk sexual behaviour known to 
favour the development of malignant and premalignant neoplastic cervical lesions among undergraduate female students in our environment.

\section{Materials and Method}

\subsection{Study Design}

This is a descriptive cross sectional study that was conducted among female undergraduates of The Benue State University (BSU) Makurdi between May and June 2016.

\subsection{Study Setting}

Benue State University is one of the two tertiary institutions situated in the Makurdi town, the capital of Benue state. The university has about 18,729 undergraduate students out of which about $40 \%$ are females. Many of the female students reside in the school provided hostels, but a significant number resides in privately owned rented houses around the university and within Makurdi town.

\subsection{Study Population}

All eligible undergraduate female students of Benue State University.

\subsection{Inclusion Criteria}

All registered undergraduate students of the university were included in the study.

\subsection{Exclusion Criteria}

All undergraduate students who were not fully registered, the postgraduate students and those who did not consent were excluded from the study.

\subsection{Sample Size}

The minimum sample size was calculated using the formula: [22]

$$
n=Z^{2} p q / d^{2}
$$

where $n=$ minimum sample size

$Z=$ standard normal deviate at $95 \%$ confidence interval which corresponds to 1.96

$P=$ Awareness of cervical cancer among undergraduates which is $71.0 \%$ based on a study done in Ibadan South West Nigeria [7].

$$
\begin{aligned}
& q=\text { complimentary probability }(=1-\mathrm{p})=1-0.71=0.29 \\
& d=\text { degree of accuracy }(=5 \%) \\
& n=(1.96)^{2} p q / \not{d}^{2}=(1.96)^{2} \times(0.71)(0.29) /(0.05)^{2}=316.4
\end{aligned}
$$

To adjust for attrition rate $=n=n / 1-f$, where $\mathrm{f}$ is the assumed no response rate. Assuming the no-response is $20 \%$, then, $n=316.4 / 1-0.2=316.4 / 0.8=$ 395.5. Consequently, a total number of 400 female undergraduates were recruited from willing respondents. 


\subsection{Data Collection}

A pretested structured questionnaire was used for individual interviews. The questionnaire was closed ended on participants' biodata, sexual history, awareness about cancer, cervical cancer and Papaniculaou's (Pap) smear screening method and their use.

A multistage sampling method was adopted in this study. First large classes were chosen to accommodate most students. Questionnaires were administered to the participants by convenience random sampling to achieve the highest sample size, after using simple random sampling to select the classrooms. Sampling was done by fellow students who were trained and equipped for the purpose. The training involved prior provision of information leaflet stating the protocol for the study in clear terms. Willing respondents completed a consent form before been given the self administered questionnaire which was anonymous identified only by numbers. In cases where respondents did not know anything about cervical cancer or Pap's smear, efforts were made by the trained interviewer to explain what the condition or procedure is.

\subsection{Data Analysis}

Data obtained was entered into and analyze using SPSS version 20.0. Initial analysis was done by generation frequency tables while further analysis was done by cross tabulation to explore statistical relationships between variables. The observed differences were subjected to chi square test and level of statistical significance was $<0.05$. Graphs and figures were drawn where necessary.

\subsection{Ethical Consideration}

Approval for the study was obtained from the management of Benue State University based on the recommendation of the Health Research Ethical Committee of the Benue State University Teaching Hospital.

\section{Results}

\subsection{Demographic Characteristics}

Four hundred respondents completed the questionnaire and 3 were incompletely filled leaving 397 (99.3\%) as the total number of analyzable questionnaire. The age of respondents ranged from 15 to 32 years with a mean age of 21 years.

Table 1 shows the socio-demographic characteristics and sexual activity of the respondents. Three hundred and fifty eight respondents (90.2\%) were 25 years and below. They were distributed across the College of Medicine and five other faculties in the University. Three hundred and seventy (93.2\%) were single while 27 (6.8\%) were married. Most of the respondents 395 (99.5\%) were Christians, and only $2(0.5 \%)$ were Muslims. Majority 171 (43.1\%) were Tiv, 151 (38.0\%) were Idoma, $42(10.6 \%)$ were Igede while $33(8.4 \%)$ were made up of other ethnic groups such as Ibo, Yoruba, Hausa etc. 
Table 1. Socio-demographic characteristics and sexual activity of the population.

\begin{tabular}{|c|c|c|}
\hline Socio-demographic characteristics & Number (n) & Percentage (\%) \\
\hline \multicolumn{3}{|l|}{ Age group 1 (years) } \\
\hline$<20$ & 142 & 35.8 \\
\hline $20-25$ & 213 & 53.6 \\
\hline $26-30$ & 35 & 8.8 \\
\hline$>30$ & 7 & 1.8 \\
\hline \multicolumn{3}{|l|}{ Marital status } \\
\hline Single & 370 & 93.2 \\
\hline Married & 27 & 6.8 \\
\hline \multicolumn{3}{|l|}{ Religion } \\
\hline Christianity & 395 & 99.5 \\
\hline Islam & 2 & 0.5 \\
\hline \multicolumn{3}{|l|}{ Tribe } \\
\hline Tiv & 171 & 43.1 \\
\hline Idoma & 151 & 38.0 \\
\hline Igede & 42 & 10.6 \\
\hline Ibo & 13 & 3.3 \\
\hline Hausa & 5 & 1.3 \\
\hline Yoruba & 4 & 1.0 \\
\hline Others & 11 & 2.8 \\
\hline \multicolumn{3}{|l|}{ Faculty groups } \\
\hline College of medicine & 90 & 22.7 \\
\hline Other faculties & 307 & 77.3 \\
\hline \multicolumn{3}{|l|}{ Sexually Activity } \\
\hline Yes & 186 & 46.9 \\
\hline No & 211 & 53.1 \\
\hline
\end{tabular}

\subsection{Sexual Activity}

One hundred and eighty six (49.6\%) of respondents were sexually active and ninety six (51.6\%) of these sexually active respondents had been exposed before the age of 20 years. Their ages for sexual debut ranged from 13 to 25 years. Their mean age at sexual debut was $18.3( \pm 2.3)$ while the modal age was 19 years. Fifty one $(27.4 \%)$ of the sexually active students had multiple sexual partners, sixty three (33.9\%) had been pregnant at one time or the other, and only $32(17.2 \%)$ of these sexually active students were using condom during intercourse.

\subsection{Awareness}

The distribution based on awareness of cervical cancer is shown in Table 2. Two hundred and eighty six (72.0\%) were aware of cervical cancer. About $88 \%$ of 
Table 2. Awareness of cervical cancer among respondents.

\begin{tabular}{|c|c|c|c|c|}
\hline \multirow{2}{*}{$\begin{array}{l}\text { Socio-demographic } \\
\text { characteristics }\end{array}$} & \multicolumn{2}{|c|}{ Awareness of cervical cancer } & \multirow{2}{*}{$x^{2}$} & \multirow{2}{*}{ P-value } \\
\hline & Aware N (\%) & Not aware N (\%) & & \\
\hline \multicolumn{5}{|l|}{ Age (years) } \\
\hline$<20$ & $105(73.9)$ & $37(26.1)$ & 0.862 & 0.650 \\
\hline $20-25$ & $153(71.8)$ & $60(28.2)$ & & \\
\hline$\geq 26$ & $28(66.7)$ & $14(33.3)$ & & \\
\hline \multicolumn{5}{|l|}{ Marital status } \\
\hline Single & $269(72.7)$ & $101(27.3)$ & 1.185 & 0.276 \\
\hline Married & $17(63.0)$ & $10(37.0)$ & & \\
\hline \multicolumn{5}{|l|}{ Religion } \\
\hline Christianity & $285(72.2)$ & $110(27.8)$ & $<0.001$ & 1.000 \\
\hline Islam & $1(50.0)$ & $1(50.0)$ & & \\
\hline \multicolumn{5}{|l|}{ Tribe } \\
\hline Tiv & $116(67.8)$ & $55(32.2)$ & 6.952 & 0.073 \\
\hline Idoma & $107(70.9)$ & $44(29.1)$ & & \\
\hline Igede & $35(83.3)$ & $7(16.7)$ & & \\
\hline Others & $28(84.8)$ & $5(15.2)$ & & \\
\hline \multicolumn{5}{|l|}{ Faculty } \\
\hline College of medicine & $79(87.8)$ & $11(12.2)$ & 14.311 & $<0.001$ \\
\hline Other faculties & $207(67.4)$ & $100(32.6)$ & & \\
\hline \multicolumn{5}{|l|}{ Sexually active } \\
\hline Yes & $128(68.8)$ & $58(31.2)$ & 1.805 & 0.179 \\
\hline No & $158(74.9)$ & $53(25.1)$ & & \\
\hline \multicolumn{5}{|c|}{ Number of sexual partners } \\
\hline None or 1 & $228(73.3)$ & $83(26.7)$ & 1.153 & 0.283 \\
\hline$\geq 2$ & $58(67.4)$ & $28(32.6)$ & & \\
\hline \multicolumn{5}{|l|}{ previous pregnancy } \\
\hline Yes & $46(73.0)$ & $17(27.0)$ & 0.017 & 0.895 \\
\hline No & $239(72.2)$ & $92(27.8)$ & & \\
\hline
\end{tabular}

students of College of Medicine were aware of cervical cancer compared to $67.4 \%$ for other faculties $(\mathrm{p}<0.001)$. There were no significant differences in awareness of cervical cancer among respondents in terms of marital status, religion, tribe, sexual activity and history of previous pregnancy. There was a fair level of awareness of cervical cancer as a preventable cancer $221(55.7 \%)$ but there was poor knowledge of individual preventive methods. Awareness of the primary preventive methods included; sexual abstinence 101 (25.4\%), Faithfulness to a partner $51(12.8 \%)$, use of condom 68 (17.1\%), Immunization 21 (5.3\%) and only $48(12.1 \%)$ knew that screening can be used to prevent cervical 
cancer.

Table 3 shows awareness of Papanicolaou's (Paps) smear among respondents. Only 104 (26.2\%) were aware of Pap smear. The remaining 293 (73.8\%) had never heard of the test. Of the College of Medicine, 53.3\% were aware of Pap smear compared to $18.2 \%$ from other faculties ( $p<0.001$ ). Also $39.2 \%$ of respondents with multiple sexual partners were aware of the test as compared to $24.3 \%$ with only one or no sexual partner $(\mathrm{p}<0.05)$. There was also a significant difference in awareness among the tribes. Other tribes mostly Ibo, Yoruba and Hausa had a higher awareness (42.4\%) compared to the indigenous tribes of Tiv

Table 3. Awareness of pap smear among respondents.

\begin{tabular}{|c|c|c|c|c|}
\hline \multirow{2}{*}{$\begin{array}{c}\text { Socio-demographic } \\
\text { characteristics }\end{array}$} & \multicolumn{2}{|c|}{ Awareness of pap smear } & \multirow{2}{*}{$x^{2}$} & \multirow{2}{*}{ P-value } \\
\hline & Aware N (\%) & Not aware $\mathrm{N}(\%)$ & & \\
\hline \multicolumn{5}{|l|}{ Age (years) } \\
\hline$<20$ & $28(19.7)$ & $114(80.3)$ & 5.707 & 0.058 \\
\hline $20-25$ & $61(28.6)$ & $152(71.4)$ & & \\
\hline$\leq 26$ & $15(35.7)$ & $27(64.3)$ & & \\
\hline \multicolumn{5}{|l|}{ Marital status } \\
\hline Single & $96(25.9)$ & $274(74.1)$ & 0.177 & 0.674 \\
\hline Married & $8(29.6)$ & $19(70.4)$ & & \\
\hline \multicolumn{5}{|l|}{ Religion } \\
\hline Christianity & $103(26.1)$ & $292(73.9)$ & 0.589 & 0.443 \\
\hline Islam & $1(50.0)$ & $1(50.0)$ & & \\
\hline \multicolumn{5}{|l|}{ Tribe } \\
\hline Tiv & $48(28.1)$ & $123(71.9)$ & 8.056 & 0.045 \\
\hline Idoma & $30(19.9)$ & $121(80.1)$ & & \\
\hline Igede & $12(28.6)$ & $30(71.4)$ & & \\
\hline Others & $14(42.4)$ & $19(57.6)$ & & \\
\hline \multicolumn{5}{|l|}{ Faculty groups } \\
\hline College of medicine & $48(53.3)$ & $42(46.7)$ & 44.330 & $<0.001$ \\
\hline Other faculties & $56(18.2)$ & $251(81.8)$ & & \\
\hline \multicolumn{5}{|l|}{ Ever had sex } \\
\hline Yes & $48(25.8)$ & $138(74.2)$ & 0.028 & 0.868 \\
\hline No & $56(26.5)$ & $155(73.5)$ & & \\
\hline \multicolumn{5}{|c|}{ Number of sexual partners } \\
\hline None or 1 & $84(24.3)$ & $262(75.7)$ & 5.130 & 0.024 \\
\hline$\geq 2$ & $20(39.2)$ & $31(60.8)$ & & \\
\hline \multicolumn{5}{|l|}{ previous pregnancy } \\
\hline Yes & $19(30.2)$ & $44(69.8)$ & 0.546 & 0.460 \\
\hline No & $85(25.7)$ & $246(74.3)$ & & \\
\hline
\end{tabular}


Table 4. Source of information on cervical cancer and pap smear among respondents.

\begin{tabular}{ccccc}
\hline \multirow{2}{*}{ Source of information } & \multicolumn{2}{c}{ Awareness of cervical cancer } & \multicolumn{2}{c}{ Awareness of pap smear } \\
\cline { 2 - 5 } & $\mathbf{N}$ & $\%$ & $\mathbf{N}$ & $\%$ \\
\hline Television & 63 & 22.0 & 21 & 20.2 \\
Health facility & 59 & 20.6 & 30 & 28.8 \\
Peers/friends & 46 & 16.1 & 15 & 14.4 \\
Newspaper & 28 & 9.8 & 13 & 12.5 \\
Youth centre & 15 & 5.3 & 4 & 3.8 \\
Radio & 31 & 10.8 & 9 & 8.7 \\
Internet & 18 & 6.3 & 6 & 5.8 \\
Total & $\mathbf{2 8 6}$ & 100 & 104 & 100 \\
\hline
\end{tabular}

(28.1\%), Idoma $(19.9 \%)$ and Igede $(28.6 \%)(\mathrm{p}<0.05)$. There were no significant differences in awareness of Pap smear among respondents in terms of age, marital status, religion, sexual exposure and previous pregnancy status.

Table 4 shows sources of information on cervical cancer and Pap smear among respondents. For cervical cancer, majority became aware through television $(22.0 \%)$, followed by health facility (20.3\%) and peers/friends (16.2\%). Other sources included radio, newspaper, parents, internet and youth centers. For Pap smear, majority of respondents had their information from a health facility (29.0\%), followed by Television (20.2\%), Peers/friends (14.5\%), and newspaper (12.4\%). Other sources included radio, parents, internet and youth centers.

\subsection{Use of Pap Smear}

Table 5 shows previous use of Pap smear among respondents. Fourteen percent of married respondents had done a Pap smear compared to $2.4 \%$ of unmarried respondents $(\mathrm{p}<0.05)$. Among religious groups, 3.3\% of Christians had done the test while no Muslim respondent did the test. With respect to sexual exposure, $5.4 \%$ of those who were sexually exposed did the test while only $1.4 \%$ of those who had never had coitus had the test $(\mathrm{p}<0.05)$. Also, 9.8\% of those who had multiple sexual partners had the test while only $2.3 \%$ of those who had a single or no sexual partner did the test $(\mathrm{p}<0.05)$. Among those who had previous history of pregnancy, $11.1 \%$ of them had the test as compared with $1.8 \%$ of those with no history of previous pregnancy $(\mathrm{p}<0.05)$. There were no significant differences among age groups, faculties and tribes with respect to those who did Pap smear test.

\section{Discussion}

Most Nigerian undergraduate are in their late teens and early twenties. In our study, majority (90.2\%) of the students were aged 25 years and below. This is similar to other findings among similar populations [7] [21]. Peculiar socioeconomic characteristics make women in the developing countries at risk of de- 
Table 5. Utilization of pap smear among respondents.

\begin{tabular}{|c|c|c|c|c|}
\hline \multirow{2}{*}{$\begin{array}{l}\text { Socio-demographic } \\
\text { characteristics }\end{array}$} & \multicolumn{2}{|c|}{ Previous use of pap smear } & \multirow{2}{*}{$x^{2}$} & \multirow{2}{*}{ P-value } \\
\hline & Yes N (\%) & No $N(\%)$ & & \\
\hline \multicolumn{5}{|l|}{ Age (years) } \\
\hline$<20$ & $4(2.8)$ & $138(97.2)$ & Invalid & \\
\hline $20-25$ & $5(2.3)$ & $208(97.7)$ & & \\
\hline$\geq 26$ & $4(9.5)$ & $38(90.5)$ & & \\
\hline \multicolumn{5}{|l|}{ Marital status } \\
\hline Single & $9(2.4)$ & $361(97.6)$ & (Yate’s) 8.585 & 0.003 \\
\hline Married & $4(14.8)$ & $23(85.2)$ & & \\
\hline \multicolumn{5}{|l|}{ Religion } \\
\hline Christianity & $13(3.3)$ & $382(96.7)$ & $<0.001$ & 1.000 \\
\hline Islam & $0(0.0)$ & $2(100.0)$ & & \\
\hline \multicolumn{5}{|l|}{ Tribe } \\
\hline Tiv & $6(3.5)$ & $165(96.5)$ & Invalid & \\
\hline Idoma & $3(2.0)$ & $148(98.0)$ & & \\
\hline Igede & $1(2.4)$ & $41(97.6)$ & & \\
\hline Others & $3(9.1)$ & $30(90.9)$ & & \\
\hline \multicolumn{5}{|l|}{ Sexual Activity } \\
\hline Yes & $10(5.4)$ & $176(94.6)$ & 4.881 & 0.027 \\
\hline No & $3(1.4)$ & $208(98.6)$ & & \\
\hline \multicolumn{5}{|c|}{ Number of sexual partners } \\
\hline None or 1 & $8(2.3)$ & $338(97.7)$ & (Yate’s) 5.689 & 0.017 \\
\hline$\geq 2$ & $5(9.8)$ & $46(90.2)$ & & \\
\hline \multicolumn{5}{|l|}{ previous pregnancy } \\
\hline Yes & $7(11.1)$ & $56(88.9)$ & (Yate's) 11.576 & 0.001 \\
\hline No & $6(1.8)$ & $325(98.2)$ & & \\
\hline
\end{tabular}

veloping cervical cancer [7] [21] and these risks were found among our respondents. For example many of them were sexually active (49.6\%) at this young age. Of the sexually active respondents, $46.2 \%$ had multiple sexual partners, $33.3 \%$ had been pregnant, only $17.2 \%$ had used condom and up to $21 \%$ had developed a sexually transmitted infection. The risk factors identified in this study were similar to previous studies [7] [21] [23], which are likely to expose the female undergraduate students to the risk of contracting Human Papilloma Virus (HPV) infection and possible progression to cervical cancer.

Awareness of cervical cancer was high with no significant difference in awareness among groups except Medical students who had a significantly higher level of awareness similar to another study in Enugu, Nigeria [13] which can be explained by their exposure to the information on cervical cancer during train- 
ing. However, there was poor knowledge of both primary and secondary prevention methods. For primary prevention, only a few knew that sexual abstinence, faithfulness to partners, use of condom and immunization were methods of cervical cancer prevention. For secondary prevention of cervical cancer, only $26.2 \%$ were aware of Pap smear and majority had never heard of the test. There is need for these students to be aware that primary prevention will prevent them from getting exposed to the HPV and secondary prevention through screening will lead to early detection of the disease process and subsequent management to prevent invasive cancer. The determinant factors for being aware of Pap smear were being a Medical student and having multiple sexual partners. This differs from a study done in Ibadan [7] where medical students and married women had more awareness about the test. As shown in Table 4, the main sources of information for knowledge of cervical cancer and Pap smear were the mass media, health facilities and peers. This is similar to a study done in Ibadan [7] among similar groups. This shows that these are good avenues through which valuable knowledge can be disseminated.

In this study, the utilization of Pap smear among female undergraduates was only $3.3 \%$ which was much lower than the $26.2 \%$ who had knowledge of Pap smear. This level of utilization was similar to a study done in Durban [24], South Africa (where only 7 out of 169 students i.e. $4.1 \%$ did the test). The findings were however much less than findings from Ibadan [7]. One major similarity among all these studies including ours is that the level of awareness translated into much lower levels of utilization. This low level of awareness and utilization of Pap smear underscores the importance of exposing these students to the knowledge and use of Pap smear as a screening tool. It was however observed that married women, those who were sexually active and those who had multiple sexual partners had a more significant tendency of doing the test than other groups. This is reassuring because these are the groups that have a higher tendency of exposure to HPV and hence development of premalignant lesions that can progress to cervical cancer. The main reasons for not doing the test were lack of awareness about the usefulness of the test, reluctance and cost. Similar reasons were obtained from previous studies [7].

\section{Conclusions}

This study shows that there was high level of awareness of cervical cancer in the study population, but the knowledge and use of Pap smear was low. It was also found that methods of prevention of cervical cancer were poorly understood though the risk factors for cervical cancer were prevalent among these undergraduates.

It is therefore important that concerted efforts should be made to educate this category of students about cervical cancer and its prevention strategies, through the mass media, youth centers, health facilities talks and regular cytological screening. 


\section{Limitations of the Study}

This study had some limitations that may have arisen as a result of the methodology. Although the questionnaire was anonymous some of the survey questions and information provided on cervical cancer and Pap smear could have given a clue to the anticipated answers and thus biased the outcome of this study. Also, a large percentage of the study population was made up of medical students who are already knowledgeable about the issues under investigation and this too could have had a favorable bias on the outcome of the study. Behavioral attitudes were self-reported and some students may have been reluctant to give very personal sensitive information especially involving risky sexual conduct even though their confidentiality was assured, which could have adversely impacted on the study results. Finally, the results of this study may not be generalized since it was conducted in only one university, and validating the results obtained may require a large sample.

\section{References}

[1] Ferlay, J., Bray, F., Pisani, P. and Parkin, D.M. (2001) GLOBOCAN 2000: Cancer Incidence, Mortality and Prevalence Worldwide. IARC Cancer Base No. 5. International Agency for Research on Cancer, Lyon.

[2] Parkin, D.M., Bray, F., Ferlay, J. and Pisani, P. (2005) Global Cancer Statistics, 2002. CA: A Cancer Journal for Clinicians, 55, 74-108. https://doi.org/10.3322/canjclin.55.2.74

[3] Oche, M.O., Kaoje, A.U., Gana, G. and Ango, J.T. (2013) Cancer of the Cervix and Cervical Screening: Current Knowledge, Attitude and Practices of Female Health Workers in Sokoto Nigeria. International Journal of Medical Sciences, 5, 184-190.

[4] Makwe, C.C. and Anorlu, R.I. (2011) Knowledge and Attitude towards Human Papilloma Virus (HPV) and Cervical Cancer and HPV Vaccine among Female Nurses at a Tertiary Hospital in Nigeria. International Journal of Women's Health, 3, 313-317. https://doi.org/10.2147/IJWH.S22792

[5] Curado, M.P., Edwards, B., Shin, H.R., Ferlay, J., Heanue, M. and Boyle, P., Eds. (2007) Cancer Incidence in 5 Continents Vol. IX. IARC Scientific Publications No. 160. International Agency for Research on Cancer Press, Lyon.

[6] World Health Organisation. Human Papilloma Virus (HPV) and Cervical Cancer. Fact Sheet. Uploaded June 2016.

[7] Ayinde, O.A., Omigbodun, A.O. and Ilesanmi, O.A. (2004) Awareness of Cervical Cancer, Papanicolaou's Smear and Its Utilization among Female Undergraduates in Ibadan. African Journal of Reproductive Health, 8, 68-80. https://doi.org/10.2307/3583394

[8] Olukoya, A.A. (1989) Cancer of the Breast and Cervix in Nigerian Women and the Role Of Primary Health Care. Nigerian Medical Practitioner, 18, 26-30.

[9] Balogun, M.R., Odukoy, O.O., Oyediran, M.A. and Ujomu, P.I. (2012) Cervical Cancer Awareness and Preventive Practices: A Challenge for Female Urban Slum Dwellers in Lagos Nigeria. African Journal of Reproductive Health, 16, 75-82.

[10] Leyden, W., Manos, M., Geiger, A.M., Weinmann, S., Taplin, S.H., et al. (2005) Cervical Cancer in Women with Comprehensive Health Care Access: Attributable Factors in the Screening Process. Journal or National Cancer Institute, 97, 675-683. 
https://doi.org/10.1093/jnci/dji115

[11] World Health Organisation (2002) Cervical Cancer Screening in Developing Countries: Report of a WHO Consultation.

[12] Omigbodun, A.O. and Akanmu, T.I. (1991) Clinicopathologic Correlates of Disease Stages in Nigeria Cervical Cancer Patients. Journal of Obstetrics \& Gynaecology of Eastern and Central Africa, 9, 79-81.

[13] Aniebue, P.N. and Aniebue, U.U. (2010) Awareness and Practice of Cervical Cancer Screening among Female Undergraduate Students in a Nigerian University. Journal of Cancer Education, 25, 106-108. https://doi.org/10.1007/s13187-009-0023-z

[14] WHO (2000-2001) Exploring Adolescent Reproductive Health. Research on Reproductive Health at WHO. Biennial Report, 43-45.

[15] Cothran, M.M. and White, J.P. (2002) Adolescence Behaviour and Sexually Transmitted Diseases. Health Care for Women International, 23, 306-319. https://doi.org/10.1080/073993302317346352

[16] Nnodu, O., Erinosho, L., Jamda, M., Olaniyi, O., Adelaiye, R., Lawson, L., et al. (2010) Knowledge and Attitude towards Cervical Cancer and Human Papilloma Virus; A Nigerian Pilot Study. African Journal of Reproductive Health, 14, 95-108.

[17] Adewale, I. (2007) Cervical Cancer in Africa. Why Is It So Common. Plenary AORTIC2007 6th International Cancer Conference, Cape Town.

[18] Scholfield, M.J., Sanson-Fisher, R., Halpin, S. and Redman, S. (1994) Notification and Follow-Up of Pap Test Results: Current Practice and Women's Preferences. Preventive Medicine, 23, 276-283. https://doi.org/10.1006/pmed.1994.1039

[19] Anonymous (1984) Cervical Screening: Editorial. The British Journal of Family Planning, 10, 1-2.

[20] Coffey, P., Arrossi, S., Bradly, J., Dzuba, I. and White, S. (2004) Improving Screening Coverage Rates of Cervical Cancer Screening Programs: A Focus on Communities Cervical Cancer Prevention Issues In-Depth No. 4. Alliance for Cervical Cancer Prevention (ACCP) Seattle.

[21] Arowojolu, A.O., Ilesanmi, A.O., Roberts, A.O. and Okunlola, M.A. (2002) Sexuality, Contraceptive Choices and AIDS Awareness among Nigerian Undergraduates. African Journal of Reproductive Health, 6, 60-70. https://doi.org/10.2307/3583131

[22] Araoye, M.O. (2003) Subjects Selection. In: Araoye, M.O., Ed., Research Methodology with Statistics for Health and Social Sciences, Nathadex Publishers, 115-129.

[23] Isa, I.A., Olugbenga, O., Gani, I. and McFubara, K. (2013) Cervical Cancer Screening among Female Undergraduates and Staff in the Niger Delta Region of Nigeria. OJOG, 3, 61-66. https://doi.org/10.4236/ojog.2013.31014

[24] Mohammad, E.H. (2013) Awareness of Cervical Cancer, Papanicolaou's Smear and Its Utilization among Female Undergraduates in Durban, South Africa. JCRT, 9, 25-28. 
Submit or recommend next manuscript to OALib Journal and we will provide best service for you:

- Publication frequency: Monthly

- 9 subject areas of science, technology and medicine

- Fair and rigorous peer-review system

- Fast publication process

- Article promotion in various social networking sites (LinkedIn, Facebook, Twitter, etc.)

- Maximum dissemination of your research work

Submit Your Paper Online: Click Here to Submit

Or Contact service@oalib.com 